\section{Injury prevention: an intranational, multinational, international, transnational or global journal?}

\author{
Roderick J McClure
}

I might have asked the question, 'Does Injury Prevention publish intradisciplinary, multidisciplinary, interdisciplinary, transdisciplinary or global research?'. While I did not on this occasion, the analogy is useful in its identification of the critical aspects of the question asked.

A discipline is a clearly delineated area of study supported by an internally consistent epistemology. ${ }^{1}$ Intradisciplinary research works within the boundaries that circumscribe the discipline. Multidisciplinary research draws knowledge from different disciplines, and summatively, combines this knowledge to create new insights. ${ }^{2}$ Interdisciplinary research compares and contrasts knowledge from different disciplines, explores the links and interactions between them and uses the between-discipline dynamic to generate knowledge. ${ }^{2}$ Transdisciplinary research dissolves the disciplinary boundaries and uses the disciplinary DNA from a number of sources to create a new epistemological entity. ${ }^{2}$ Global research goes one step beyond this into the realm of methodological pluralism, with the obligatory integration of multiple perspectives in a globally consistent approach to the development of new knowledge. ${ }^{3}$

Injury Prevention receives manuscripts describing the nature and extent of the injury problem in the authors' country of residence, from authors resident in countries across the globe. These intranational research reports are of high value particularly to citizens of the relevant country, as they help focus intervention effort on the specific population needs. In accordance with the notion, 'local data for local prevention', these manuscripts provide information about context-specific risk factors and about evidence of effectiveness of interventions. When the research approach is innovative, reports of intranational research describe methods that could be used in other settings, in other countries. To the extent measures of effect are generalisable beyond the study population, findings from intranational analytic studies may produce measures of effect that are

Correspondence to Dr Roderick J McClure, School of Rural Medicine, University of New England, Armidale, NSW 2351, Australia; rmcclure@une.edu.au universally applicable. The vast majority of all manuscripts submitted to Injury Prevention describe intranational research. Given the major benefit of intranational research is to citizens of the country in which the study was undertaken, and replication studies for all injury topics for all nations are clearly not something Injury Prevention can accommodate, intranational research is probably best published in proportion to the national distribution of the journal's readership.

The multinational nature of Injury Prevention follows, in part, from the Journal's publication of intranational manuscripts from many countries. The summative consequence of this knowledge produced in different countries reveals broader more detailed information about the distribution and determinants of injury and the range of contexts, interventions and outcomes. Manuscripts that are themselves reports of multinational research studies can achieve a summative contribution within the scope of a single study when the study populations are drawn from more than one national location. Other than having the advantage of standardised data collection and analysis methods, multinational studies might not add substantially to information obtained from meta-analyses of intranational ones. A moderate number of manuscripts submitted to Injury Prevention describe multinational research and can be accommodated within usual manuscript selection decision making processes.

The powerful, and much rarer manuscript type, for which Injury Prevention is an ideal place of publication, is the international manuscript that describes data collection from different countries AND includes analyses that compares and contrasts the information obtained. It is in the exploration of differences between the injury rates in populations across the globe that lies to the most important discoveries. ${ }^{4}$ There are only a small number of manuscripts of this kind currently being submitted to the journal.

Transnational manuscripts, while not common, are published in Injury
Prevention, sometimes in the form of conceptual discussions or commentaries, but also in manuscripts describing the activities of transnational organisations and agencies. These projects tend not to focus on country-specific factors, but instead use material from many countries to develop approaches that could be adopted by any. It is understandably difficult for individual researchers or research groups to conduct and publish work of this scale. However, given the important impact of transnational injury prevention activity, the field may benefit from researchers' increased efforts to organise themselves into large transnational collectives.

The Journal is also global, at least in the sense that its focus is on publishing the science that can be used to support the injury-related health of all people whomever they are and wherever they live. The Journal accepts a plurality of disciplines and acknowledges the importance of integrating knowledge from different countries, regions and perspectives in the pursuit of useful evidence.

I would argue Injury Prevention is it all: an intranational, multinational, international, transnational and a global scientific journal. I am not so sure though, how many would agree.

Funding The authors have not declared a specific grant for this research from any funding agency in the public, commercial or not-for-profit sectors.

Competing interests None declared.

Patient consent Not required.

Provenance and peer review Commissioned; internally peer reviewed.

(C) Author(s) (or their employer(s)) 2018. No commercial re-use. See rights and permissions. Published by BMJ.

\section{Check for updates}

To cite McClure RJ. Inj Prev 2018;24:249-249.

Inj Prev 2018;24:249-249.

doi:10.1136/injuryprev-2018-042906

\section{REFERENCES}

1 Choi BC, Pak AW. Multidisciplinarity, interdisciplinarity, and transdisciplinarity in health research, services, education and policy: 3. Discipline, inter-discipline distance, and selection of discipline. Clin Invest Med 2008;31:41-8.

2 Choi BC, Pak AW. Multidisciplinarity, interdisciplinarity and transdisciplinarity in health research, services, education and policy: 1. Definitions, objectives, and evidence of effectiveness. Clin Invest Med 2006:29:351-64.

3 Wilber K. A theory of everything, An integral vision for business politics science an spirituality. Boston MA: Shambhala Publications, 2001.

4 Rose G. The strategy of preventive medicine. Oxford: Oxford University Press, 1992. 